\title{
Direct Participation and Employee Learning at Work
}

\section{Hande Inanc', Ying Zhou', Duncan Gallie ${ }^{3}$, Alan Felstead ${ }^{4}$, and Francis Green ${ }^{5}$}

\begin{abstract}
The creation of a learning environment at work has been seen as an essential concomitant of the growth of an advanced economy. This article explores the implications of direct participation for different types of employee learning, drawing upon the British Skills and Employment Surveys of 2006 and 2012. It confirms that direct participation is strongly associated with enhanced learning opportunities at work but finds important differences in the benefits of specific forms of direct participation. Moreover, direct participation was found to be particularly important for those in less favorable work contexts with respect to technological level and skill.
\end{abstract}

\section{Keywords}

task discretion, organizational participation, training, workplace learning, skills

\footnotetext{
'OECD, Paris, France

${ }^{2}$ University of Surrey, Guildford, UK

${ }^{3}$ University of Oxford, Oxford, UK

${ }^{4}$ Cardiff University, Cardiff, UK

${ }^{5}$ Institute of Education, London, UK
}

\section{Corresponding Author:}

Hande Inanc, OECD, 2 André Pascal, Paris 75016, France.

Email: hande.inanc@oecd.org 
The earliest advocates of high involvement management pointed to the benefits of direct participation for the use and development of workplace skills (Lawler, 1986; Lawler \& Ledford, 1992). Subsequent studies, mainly drawing on individual case research or intra-industry firm comparisons, have provided a measure of support that this is indeed the case (inter alia: Appelbaum, Bailey, Berg, \& Kalleberg, 2000; Heller, Pusic, Strauss, \& Wilpert, 1998; Hirschhorn, 1984; Thompson, 2005). But variations in the design of studies and in the concepts of participation they deploy make comparability difficult, while the relative dearth of evidence that is representative of the wider range of employment situations has made it difficult to assess the generalizability of findings or to address a number of key issues about the nature of the relationship between direct participation and learning (with some exceptions, e.g., Felstead, Gallie, Green, \& Zhou, 2010).

In this article, we seek to advance understanding in four principal ways. First, we examine which types of direct participation are most important for specific types of employee learning - influence over decisions about individual work activity or influence over wider organizational decisions. Second, we consider what types of learning are improved, whether it is primarily relatively formal learning opportunities based on training or learning more directly derived from activities at work. Third, we assess whether the effects of participation are relatively general across the workforce or are relevant primarily to specific types of employees - in particular, those working in advanced technology settings and highly skilled employees. Finally, we test whether the connection between participation and learning could be artefactual, resulting from person-fixed effects. Employees may be sorted into jobs because of their prior job preferences, and personality traits, with some types of employee inherently more likely to benefit both from participation and from learning.

\section{Types of Direct Participation}

The view that direct participation enhances learning is compatible with rather different assumptions about the specific mechanisms through which this occurs. The concept of participation has come to cover diverse practices for involving employees in decision making (Gallie \& Zhou, 2013a; Gonzalez, 2009; Heller et al., 1998; Wilkinson, Gollan, Marchington, \& Lewin, 2010; Zhou, 2009). In particular, some have emphasized the influence of employees over their immediate work tasks, while others have pointed to the importance of their influence 
over higher level organizational decision making. This raises the issue of whether a specific type of participation is likely to be more effective than others in enhancing learning.

The principal focus in the sociological literature has been with direct participation in the sense of task discretion, that is to say the ability of employees to influence the way they carry out their immediate work activities. This was the primary concern of researchers in the neoMarxian tradition who highlighted the destructive effects of Taylorist organizational principles on employees' control over their jobs (Braverman, 1974). The effect of such policies, it was argued, was to undermine opportunities for creativity and use of initiative and thereby the potential for self-development through work. While there has been considerable controversy about the long-term direction of change, there has been general agreement that forms of work organization that give employees greater discretion over their task activities tend to be beneficial for learning and self-development (Appelbaum et al., 2000; Felstead, Fuller, Jewson, \& Unwin, 2009; Felstead et al., 2010; Hirschhorn, 1984; Kalleberg, 2011).

A more intermittent concern has been with direct participation in the sense of organizational participation or employee voice with respect to wider organizational decisions. There was an early literature that argued that such channels were important for managerial objectives of facilitating organizational change (Blumberg, 1968). This contained an implicit argument about the learning properties of such practices. Direct consultation of employees helped diminish resistance to organizational change by increasing understanding of why it was necessary, as well as by allowing for modifications in the light of employee views.

From the 1980s, such arguments were reinforced by a new management literature that emphasized much wider benefits to employers of employee involvement in decision making (Walton, 1985). In the context of the transition to a knowledge-based economy and of the use of increasingly complex technologies, it was thought to be a condition of achieving the level of skills required of the workforce and ensuring that full use was made of such skills. Direct participation through consultative procedures came to be seen an essential part of the requirements for high-performance management systems (Boxall \& Purcell, 2010). They were presented as win-win systems with benefits for both management and employees.

This optimistic view about the benefits of organizational participation was contested in the 1990 s by a more critical literature. Rather than offering any genuine form of voice by which employees could improve 
their well-being, such mechanisms were seen as a form of ideological manipulation designed to undermine trade union influence and entice employees to identify with the objectives of the organization, at the expense of their own interests (Legge, 1995; Purcell, 1993; Willmott, 1993). As such, they were unlikely to lead to any significant enrichment of employee skills.

There is widespread agreement that task discretion should be conducive to learning. There is, however, notably less agreement about the likely implications of organizational participation. From one perspective, it also should increase employee learning and skill development, while from another, which views it as a form of pseudo-participation, it should make no difference.

\section{Formal and Informal Learning at Work}

There has been a growing consensus from the 1980s that the combination of increasingly sophisticated technologies and greater internationalization of markets has placed greater demands on the skill level and learning capacity of employees. In early discussions, the emphasis was primarily upon the need for higher levels of scientific and technical knowledge. This was the scenario that informed the notion of the transition to a "knowledge economy," most saliently embodied in the European Union's Lisbon Strategy statement (European Council, 2000). But it built upon an extensive prior academic literature: economists' theories of skill-biased technical change (Card \& DiNardo, 2002) and sociologists' theories of postindustrial and informational societies which predicted increasing demand for high-level theoretical and technical skills (Aoyama \& Castells, 2002; Bell, 1974; Castells \& Aoyama, 1994).

While one implication of such changes in skill demands was that organizations would need to raise the qualification levels they expected of new recruits, it also was commonly recognized that they would require continuous updating of skills through increased employer provision of training (Conceição, Heitor, \& Lundvall, 2003). The literature has focused primarily on the quantity of training provision: the proportion of employees who are given training and the duration of the training they receive. The quality of training provision has been relatively neglected - in part because of the scarcity of good data. Yet, this would seem to be a particularly crucial factor with respect to arguments about the need to sustain rising levels of skill.

In the 1990s, the emphasis on learning in the form of formal knowledge was challenged by a literature on the growing importance in the 
modern economy of competences or practical expertise. These included not only technical know-how but also problem-solving and communicative skills. This perspective, which originated in cognitive psychology, became increasingly influential in educational and ergonomic theories and was finally taken up by an influential current of human resource management theory (Oiry, 2003). It argued that there is a considerable gap between the possession of formal knowledge and the capacity for effective work performance. Even in work that appeared relatively routine, fine-graded observation revealed that the production process required the continual use of practical expertise, acquired through experience on the job and the sharing of knowledge between employees, to cope with unanticipated variances in the functioning of machinery, or the quality of materials (Darrah, 1996; Wenger, 1998). These factors were thought to be particularly important with more sophisticated forms of technology and in more competitive global markets, where rapid response to changes in product or service demand became ever more essential for economic success (Hirschhorn, 1984).

In contrast to formal knowledge, practical expertise was held to be acquired primarily through a process of informal learning. Arguably, there are two principal ways in which such learning may occur. The first is through the process of task activity itself-for instance, in problem solving through trial and error by the individual employee. The second derives from knowledge sharing between employees or involvement in "communities of practice" (Darrah, 1996). Knowledge sharing is important both in terms of direct knowledge transfer but also because employees will be able to accomplish their own tasks more effectively if they understand how their work relates to the wider work process and to the tasks of others (Boreham, Fischer, \& Samurcay, 2004).

An issue that received relatively little attention in the literature is whether different types of direct participation might have distinct consequences for different forms of learning. Yet this seems quite plausible. The literature on informal learning has emphasized the importance of the immediate nature of work activities and of the social relations in which they are embedded. These are likely to be more directly affected by the extent of task discretion because they depend upon the opportunities for the use of initiative and problem solving on the job. Whereas decisions about training are more likely to be taken at a relatively central workplace level, given the economies of scale that can come from an overall organizational policy and the greater resources that need to be mobilized. Organizational participation then could be 
expected to have the strongest effect on the quantity and quality of training provided.

\section{Differential Effects for Different Types of Employees}

Theories of participation often assume that their beneficial effects are very general across different types of employee. But some arguments have focused on specific contexts in which it is effective. A particularly influential tradition of thought has highlighted its importance in the context of advanced technologies. The consistent thread in these diverse arguments is the role of uncertainty in the production process (Blauner, 1964; Hirschhorn, 1984). Advanced computerized or automated technologies are very effective with respect to the predictable part of the production process, but at the same time, they amplify the negative consequences of unpredictable events. As they tend to be associated with much higher production speed and volume flows, equipment failure produces correspondingly greater losses. In these settings, there is then an enhanced need to anticipate problems, react quickly, and take finely tuned action to limit losses and downtime. This, it is argued, requires an in-depth knowledge by employees not only of their immediate tasks but also of the wider work process, necessitating continuing learning on the job. A high level of task discretion is then thought to be especially important for learning in the context of advanced technology.

It also could be expected that direct participative mechanisms would be more effective in promoting the learning of those in more skilled positions, more intensively involved in knowledge-based work (Thompson, 2005). Such employees may be better equipped in terms of both past education and experience at work to take advantage of participative channels and the new learning demands of such jobs may be greater. In contrast, those in low-skilled work may lack the technical and interpersonal skills, as well as the self-confidence, to gain full benefit from potential channels of voice, while the contents of their jobs may be too restrictive to give much scope for informal learning.

\section{Person-Fixed Effects}

It is possible that the connections shown between direct participation and learning are artefactual, reflecting individual differences among employees that account for both higher levels of participation and better learning opportunities. For instance, individuals with stronger preferences with respect to use of initiative or certain learning styles 
may have chosen their employer to obtain jobs that provided both high levels of task discretion and better training. A similar connection might arise from differences in terms of personality characteristics (for instance, self-discipline, enthusiasm, openness to new experiences, and creativity) that may affect both the level of task discretion and the learning opportunities given to employees in their jobs.

Based on the discussion above, this article focuses specifically on four main questions:

- First, whether both task discretion and organizational participation are conducive to learning at work.

- Second, whether there are differences in the effects of task discretion and organizational participation on formal and informal learning.

- Third, whether direct participation is more likely to be linked to enhanced learning in conditions of advanced technology and more skilled work.

- Fourth, whether any empirical associations between direct participation and learning can be accounted for by person fixed-effects.

\section{Data, Measures, and Analytic Procedure}

\section{Data}

The analyses are based upon the most recent waves of the British "Skills and Employment Survey," carried out, respectively, in 2006 and 2012. They include indicators of task discretion, organizational participation, training and informal learning, together with a wide range of questions on the individual characteristics of employees and other aspects of their work situation. As ever there are trade-offs in terms of types of data. Like other national surveys, the Skills and Employment Surveys rarely provide extensive batteries of questions for the measurement of specific concepts - typically constraining indices to be based on three or four items. $^{2}$ But they have the great benefit of breadth of coverage of different aspects of the work situation and enhanced generalizability.

The surveys provide representative samples of individuals in employment in England, Scotland, and Wales, aged 20 to 65. Interviews were conducted at home, with a response rate of $62 \%$ in 2006 and $49 \%$ in 2012. We focus on employees, with sample numbers of 6,829 in 2006 and 2,735 in 2012. Sample weights were computed to take into account the differential probabilities of sample selection, the oversampling of certain areas, and some small response rate variations between groups 
(defined by sex, age, and occupation). All of the analyses that follow have been weighted accordingly, ${ }^{3}$ with weights scaled to reflect initial effective sample sizes.

The survey is cross-sectional and therefore cannot provide direct information on causal sequences. We use the term effect in the sense of statistical, not causal, effect. Our approach is to assess the consistency of the pattern of the data with the expectations of different theoretical arguments.

\section{Measures of Direct Participation}

An initial factor analysis of a range of items about influence at work confirmed that influence over the immediate work task and wider influence over organizational decisions were two distinct dimensions. Two measures were then constructed representing, respectively, individual task discretion and organizational participation. The measures have the same score range, facilitating interpretation of the relative strength of effects.

The measure of individual task discretion was derived from four questions designed to assess how much personal influence people had over specific aspects of their work. They were asked: "How much influence do you personally have on ... how hard you work; deciding what tasks you are to do; deciding how you are to do the task; deciding the quality standards to which you work?" There was a 4-point response scale: a great deal (of influence), a fair amount, not much or none at all. Response points were scored from 0 for none at all to 3 for a great deal. As the four items had a Cronbach's alpha of .77, a summary index was created by averaging across the four items.

Our measure of organizational participation is constructed from a series of questions. Respondents were asked initially: "At your workplace, does management hold meetings in which you can express your views about what is happening in the organization?" For those who could express their views, additional questions were asked about six issue areas on which consultation took place. The objective was to construct a measure that reflected the relative strategic importance of the issues on which employees could express their views. Issues were grouped into those relating to more immediate work activity (working practices, health and safety, and training), those concerned with decisions about products (planned changes in products or services), and those involving longer term financial issues (the financial position of the organization and investment plans). 
A 4-point scale of organization participation was constructed from these categories running from 0 for no participation, 1 for participation limited to work activity issues, 2 for participation limited to work activity and product decisions, and 3 for participation that included strategic issues (investment plans and financial situation). Hence, the higher the score, the more involvement employees have in strategic decisions. The hierarchical nature of the measure is reflected in the fact that the average number of issues on which employees could express their views increased across the successive levels. The measure was also strongly associated with the perceived influence that employees felt they could exercise over organizational changes that could affect their work (not reported).

\section{Measures of Learning}

In assessing the effects of direct participation for learning, we focus on three key dimensions: training receipt, training quality, and informal learning. Training receipt refers to whether a person participated in training (training incidence) and the duration of the training (training duration). People were first asked whether they had done any training and education in connection with their current job, including instruction both away from and on the job (which we term training incidence). Those who had participated in training were then asked how many separate days were involved in the training. Given that recall is likely to be approximate, we have grouped responses into five categories of training duration, ranging from those who received zero training to those who received training that lasted for more than 50 days.

The survey also contained a number of questions relating to training quality. Employees were asked whether their training helped them to improve the way they did their job, improve their skills, led to a qualification, or a credit toward a qualification and provided them with skills that were useful for another employer either in the same industry or a different industry. As the five items had a scale alpha of .85 , we have standardized the individual items and averaged them into an additive scale.

With respect to informal learning, there were also a range of items: whether or not the job required learning new things, spotting problems or faults, working out the cause of problems or faults, thinking of new solutions to problems, and helping colleagues to learn new things. Given the distinctions drawn in the literature, we have constructed a job-learning demands measure from the first four items (with a scale alpha of .81) 
and a knowledge-sharing measure based on the last item. (Summary statistics for learning and participation variables are presented in the Appendix.)

\section{Measures of Advanced Technology and Skills}

The indicator of advanced technology was derived from four items which were averaged into an additive scale: whether one's job involves the use of computerized or automated equipment, the proportion of employees working with such equipment in the workplace, and the importance and complexity of use of computer or computerized equipment at work (see Appendix for question items). Respondents are divided into three categories based on their score on the indicator, with approximately the same proportion in each category.

Skill level is proxied by occupational class as defined by the first digit categories of the Standard Occupational Classification. To give sufficient sample numbers, these were aggregated into three skill levels: high skill (managers, professionals, and associate professionals), medium skill (administrative and secretarial, skilled trades and personal service), and low skill (sales, operatives, and elementary).

\section{Measures of Person-Fixed Effects}

Employees' preferences to work and training were measured by a set of questions capturing the importance they attach to a job where they can use their initiative, the extent of choice individuals had over the type of job they would get when they were looking for their current job, and the level of information they had about the training opportunities provided by their current employer.

Learning dispositions, which were examined for the first time in the 2012 survey, were measured by a set of questions about how individuals deal with problems and tasks they encounter in general (not necessarily in a work context). The questions (Appendix) are designed to capture the extent to which workers are interested in learning new things, appraise evidence in relation to their previous knowledge, and experience and enjoy examining ideas in greater depth.

With respect to personality, questionnaire space prevented the introduction of extended sets of measures. But the survey contained a very condensed set of indicators (Appendix) of the "Big Five" personality traits-Extraversion, Agreeableness, Conscientiousness, Emotional Stability, and Openness - that were also introduced for the first time 
in the 2012 survey. We included the scales derived from the short form version of these scales, designed and validated for use where interview time was scarce in large-scale surveys (Gosling, Rentfrow, \& Swann, 2003; Muck, Hell, \& Gosling, 2007).

\section{Methods}

The effects of direct participation are estimated using regression models that include a range of controls for factors that potentially could affect learning outcomes and that might account for any relationship between participation and learning. These include individual characteristics: sex and age; job characteristics: type of work; occupational class: type of employment contract (part time and temporary); and finally organizational characteristics: the presence of trade union organization, type of ownership (public or private), and firm size (for their potential relevance, see inter alia Halldén, 2015).

Estimates for training incidence are based on logistic regression, as the outcome variable is binary. Ordinary least square estimates are reported for training quality and learning demands which are measured with standardized indices. For training duration and knowledge sharing, which have shorter scales, estimates from ordered logistic regression models are reported. ${ }^{4}$ All the estimates presented in the article are based on constant sample sizes for all variables other than training quality (which is applicable only for those who received training).

\section{Results}

\section{Direct Participation and Learning}

A first point to note is there is considerable variation in employees' learning opportunities with respect to their individual characteristics, type of work, and organizational environment (Table 1). Taking individual characteristics first, our evidence showed a strong negative relationship between age and the three aspects of training (its incidence, duration, and quality). As has been well established in the literature, older workers are less likely to receive training and our results show that they are also considerably less likely to receive longer training (Canduela et al., 2012; Felstead, 2010). While there was no general relationship between age and informal learning, the oldest cohort was also less likely to learn through knowledge sharing. There were no sex differences with respect to either training or knowledge sharing, but 


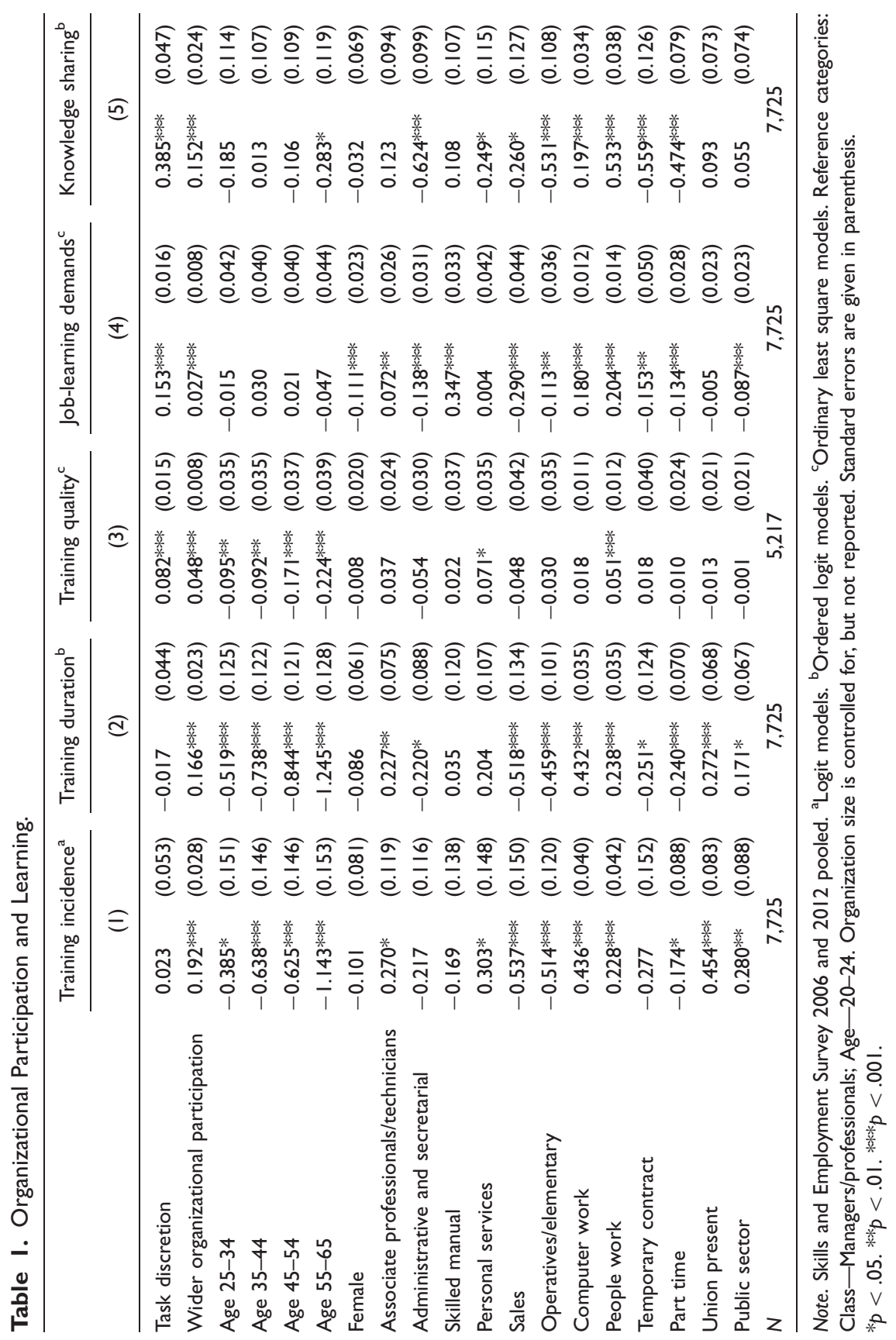


women were significantly less likely to develop their skills in carrying out their tasks.

The type of job was also closely related to learning. Consistent with previous literature, there was a clear class differential in training opportunity and informal learning. Compared with managers and professionals, as well as associate professionals and technicians, those in lower class positions (sales, operatives, and elementary workers) tended to have poorer training chances and were less likely to be in jobs that had high learning demands or involved knowledge sharing with colleagues. However, there was a diverse pattern among those in intermediate class positions: Administrative and secretarial employees were also disadvantaged with respect to these aspects of learning, while this was not the case for skilled manual workers. Employees who worked in a highly computerized environment and those whose work involved intensive interaction with people outside the organization were both significantly more likely to receive training and to have the benefit of longer courses and being more likely to learn informally through individual job activity or discussion with colleagues. In contrast, nonstandard workers, that is, those in part-time or temporary jobs, were notably disadvantaged with respect to informal learning activities and receiving long training.

Finally, with respect to the organizational environment, it was notable that the presence of trade unions tended to boost both the incidence and the duration of training (in line with findings of the literature on union presence/participation and training, i.e., Arulampalam \& Booth, 1998; Böheim \& Booth 2004), but it made no difference to the quality of training and informal learning. While working in the private sector significantly reduced both incidence and duration of training, it was the private rather than the public sector that was most conducive to individual learning on the job.

Did direct participation have any effect on learning once these controls had been taken into account? We consider first the relationship between direct participation and training incidence and duration, then turn to its implications for training quality and finally examine its association with learning demands and knowledge sharing.

Training incidence and duration. The implications of the two types of direct participation appeared to be very different. There was no evidence that higher task discretion affected either the chances of being trained or the chances of receiving longer training. In contrast, organizational participation had a significant effect on both aspects of training. This supports the view that, given the more centralized and resource 
intensive nature of training, it is influence over wider workplace decision making that is most effective in improving employees' training chances.

Training quality. Arguably, the quality of training provision is of even greater significance for both productive efficiency and employee wellbeing than just the receipt of training, yet few analyses focus on training quality. It is notable that, while only organizational participation had been important for whether or not people were given training and for the duration of training, both task discretion and organizational participation were strongly related to training quality. This suggests that formal training is more likely to be effective in improving skills where employees have the opportunity to take the initiative in testing out new knowledge in their everyday work.

Informal learning. The third aspect of learning at work that we focused upon was skill development acquired through the everyday activities of work. We distinguish learning that results from the job activity itself, say from individual problem solving and trial and error, and learning that derives from the sharing of experience between colleagues. We term these, respectively, job-learning demands and knowledge sharing.

The effects of direct participation on informal learning were very similar to those for training quality. Both task discretion and organizational participation were significantly related to higher levels of individual learning through job task activity and through knowledge sharing, although the coefficients indicate that the stronger effect came from task discretion. Task discretion clearly gave employees the scope to develop skills by experimenting with the way they did the work and sharing with colleagues the knowledge they had acquired. In contrast, organizational participation had a relatively weak association with job-learning demands, although it was more strongly related to the sharing of knowledge between colleagues.

Causal direction. The analyses above show associations but cannot in themselves show the direction of causation. It is arguable that learning leads to higher participation rather than the reverse. This issue is less problematic for organizational participation than for task discretion. It seems implausible that the complex institutional structures involved in allowing for communication and consultation within the wider workplace would be the outcome of current individual learning experiences among employees. Given the time they take to set up and the resources they require, they more probably result from prior managerial actions, 
deriving from views about appropriate human resource policies. However, it is more plausible to argue that, with new learning, employees will use more discretion while carrying out immediate work activities.

There are evident limitations to the use of cross-sectional data to establish causal direction, but it is possible to get some leverage on causal direction by taking self-report evidence about past change in task discretion. The survey contains a question that asks people: "Compared with your job five/four/three years ago [depending on when job change took place], has the amount of choice you have in the way you do your job increased, decreased, or stayed about the same?" Those who reported a change were then asked whether the amount of choice had changed a lot or a little. Combining the two variables allows for the construction of a 5point indicator of past change in task discretion.

When past change in task discretion is included in the main models instead of current task discretion, with the full set of controls, it has a highly significant effect in increasing the learning outcomes (results available from the authors upon request). A past increase in discretion made it more likely that people had recently received training, that the training was of a quality to improve their skills and external job chances, and that they benefited from informal learning on the job.

It may also be argued that the effect of direct participation on learning is likely to result from employers' adoption of a set of mutually complementary and reinforcing high-performance management practices which typically comprises training and skill development, use of semiautonomous or self-managing teams, employee involvement practices, and sophisticated performance appraisal and reward systems. These practices are often seen as forming a coherent bundle which act together to enhance organizational performance. To test this argument, a set of regression analyses have been performed to control for the effect of the management practices that are seen as indispensable components of high-performance work organizations (HPWO): the presence of semiautonomous or self-managing teams ${ }^{5}$ and the use of performance appraisal systems. In addition, the analysis has controlled for whether the organization is committed to or recognized as an Investor in People, an accreditation framework administered by the U.K. Commission for Employment and Skills to identify work organizations that are effectively managed in terms of many features of HPWO.

The results showed that autonomous types of teamwork were positively related to all aspects of training and informal learning. The presence of appraisal systems and Investor in People status was more ambivalent in their effects: Appraisals were positively related to 
training incidence and training quality but negatively affected training duration and knowledge sharing. Investor in People status has positive effects for training incidence and learning demands but negative effects for training duration. However, the effect of task discretion and organizational participation on training and learning outcomes remained largely unchanged with these controls. Moreover, there was no differential impact on learning of participation between workplaces that adopted all these high-performance management practices and those that did not (Table 2). It appears unlikely then that the effects of direct participation on skill development were either an artifact of, or contingent upon, the simultaneous adoption of other high-performance work practices.

\section{Differential Effects for Employees in High-Tech or High-Skilled Work?}

Were the effects of direct participation for learning very general across the workforce or did they vary substantially for employees in advanced technology settings or with higher skills? In the light of the debates of the literature, our initial expectations were that both working with advanced technology and working in a more skilled job would tend to accentuate the effects of direct participation on learning. But neither view was confirmed by the interaction analyses. Rather it was those working in jobs in relatively low-tech work environments that gained greatest benefit from task discretion with respect to both training receipt and learning through job activity. Similarly, task discretion had the greatest positive impact on both training and job learning among those in relatively low-skilled occupational categories, while organizational participation also had a significant positive effect on training duration and job learning for the low skilled and on training duration for those working in jobs in lower tech work environments (Table 3).

\section{Selectivity: The Possible Role of Person-Fixed Effects}

The link we observe between participation and learning could be due to person-fixed effects. Employees with a disposition to learn deeper may find participation more conducive to learning. Similarly, they could be sorted into jobs because of their prior job preferences and personality traits. The data enable us to carry out some checks to discount the possible effects of self-selection, in particular, by introducing controls for employees' preferences with respect to work and training, as well a measure designed to capture their general disposition toward learning 
Table 2. Effects of Direct Participation on Learning With Controls for HighPerformance Management Practices.

\begin{tabular}{|c|c|c|c|c|c|}
\hline & $\begin{array}{c}\text { Training } \\
\text { incidence }^{\mathrm{a}}\end{array}$ & $\begin{array}{c}\text { Training } \\
\text { duration }^{\mathrm{b}}\end{array}$ & $\begin{array}{l}\text { Training } \\
\text { quality }^{c}\end{array}$ & $\begin{array}{l}\text { Learning } \\
\text { demands }{ }^{c}\end{array}$ & $\begin{array}{c}\text { Knowledge } \\
\text { sharing }\end{array}$ \\
\hline & (6) & (7) & (8) & (9) & $(10)$ \\
\hline \multicolumn{6}{|l|}{ With HPWO controls } \\
\hline \multirow[t]{2}{*}{ Task discretion } & 0.014 & -0.024 & $0.077 * * *$ & $0.154 * * *$ & $0.383 * * *$ \\
\hline & $(0.059)$ & $(0.047)$ & $(0.017)$ & $(0.018)$ & $(0.05 \mathrm{I})$ \\
\hline \multirow[t]{2}{*}{ Wider organizational participation } & $0.147^{* * * *}$ & $0.121 * * * *$ & $0.041 * * *$ & $0.021^{*}$ & $0.134^{* * * *}$ \\
\hline & $(0.031)$ & $(0.025)$ & $(0.008)$ & $(0.008)$ & $(0.026)$ \\
\hline \multirow[t]{2}{*}{ Low influence teams } & $0.176^{*}$ & $0.140 *$ & $0.045^{*}$ & 0.013 & $0.623 * * *$ \\
\hline & $(0.078)$ & $(0.060)$ & $(0.020)$ & $(0.02 I)$ & $(0.067)$ \\
\hline \multirow[t]{2}{*}{ Semiautonomous teams } & $0.628 * * *$ & $0.363^{* * *}$ & $0.072^{*}$ & $0.113^{* *}$ & $0.886 * * *$ \\
\hline & $(0.147)$ & $(0.104)$ & $(0.030)$ & $(0.035)$ & $(0.106)$ \\
\hline \multirow[t]{2}{*}{ Self-managing teams } & -0.094 & -0.007 & $0.202^{* * *}$ & $0.114 * *$ & $1.095^{* * *}$ \\
\hline & $(0.189)$ & $(0.159)$ & $(0.038)$ & $(0.043)$ & $(0.149)$ \\
\hline \multirow[t]{2}{*}{ Appraisal systems } & $0.558 * * *$ & $-0.557^{* * *}$ & $0.075^{* *}$ & 0.041 & $-0.392^{* * * *}$ \\
\hline & $(0.095)$ & $(0.086)$ & $(0.029)$ & $(0.028)$ & $(0.083)$ \\
\hline \multirow[t]{3}{*}{ Investor in people } & $0.262 * *$ & $-0.244^{* * * *}$ & 0.033 & $0.06 I^{*}$ & -0.017 \\
\hline & $(0.088)$ & $(0.072)$ & $(0.022)$ & $(0.025)$ & $(0.073)$ \\
\hline & (II) & $(12)$ & $(13)$ & (I4) & $(15)$ \\
\hline \multicolumn{6}{|l|}{ With HPWO interactions } \\
\hline \multirow[t]{2}{*}{ Task discretion } & 0.016 & 0.033 & $0.084 * * *$ & $0.178 * * *$ & $0.379 * * *$ \\
\hline & $(0.067)$ & $(0.058)$ & $(0.022)$ & $(0.023)$ & $(0.062)$ \\
\hline \multirow{2}{*}{$\begin{array}{l}\text { Wider organizational } \\
\text { participation }\end{array}$} & $0.187^{* * *}$ & $0.175^{* * *}$ & $0.041 * * *$ & $0.023 *$ & $0.163^{* * *}$ \\
\hline & $(0.034)$ & $(0.03)$ & $(0.01)$ & $(0.010)$ & $(0.03 \mathrm{I})$ \\
\hline \multirow[t]{2}{*}{ HPWO } & 0.520 & $0.867 * * *$ & 0.066 & $0.197^{*}$ & $0.688^{* *}$ \\
\hline & $(0.295)$ & $(0.226)$ & $(0.078)$ & $(0.085)$ & $(0.242)$ \\
\hline \multirow[t]{2}{*}{ HPWO $\times$ Task Discretion } & -0.002 & -0.170 & -0.005 & -0.055 & 0.011 \\
\hline & $(0.126)$ & $(0.093$ & $(0.033)$ & $(0.034)$ & $(0.100)$ \\
\hline HPWO $\times$ Organizational & -0.052 & -0.085 & 0.012 & 0.001 & -0.059 \\
\hline Participation & $(0.069)$ & $(0.050)$ & $(0.016)$ & $(0.017)$ & $(0.052)$ \\
\hline$N$ & 6,710 & 6,710 & 4,583 & 6,710 & 6,710 \\
\hline
\end{tabular}

Note. HPWO's are those organizations where autonomous types of teams, performance appraisal systems and Investor in People schemes are present. HPWO $=$ high-performance work organizations. Skills and Employment Survey 2006 and 2012 pooled. ${ }^{a}$ Logit models. b Ordered logit models. 'Ordinary least square models. Models include all controls shown in Table I. Standard errors in parenthesis.

$*_{p}<.05$. **p $<.01$. ***p $<.001$. 
Table 3. Effects on Learning of Interactions Between Moderator Variables and Direct Participation.

\begin{tabular}{|c|c|c|c|c|c|}
\hline & $\begin{array}{c}\text { Training } \\
\text { incidence }^{\mathrm{a}}\end{array}$ & $\begin{array}{c}\text { Training } \\
\text { duration }^{\mathrm{b}}\end{array}$ & $\begin{array}{l}\text { Training } \\
\text { quality }^{c}\end{array}$ & $\begin{array}{l}\text { Learning } \\
\text { demands }^{c}\end{array}$ & $\begin{array}{c}\text { Knowledge } \\
\text { sharing }\end{array}$ \\
\hline & $(16)$ & (17) & $(18)$ & $(19)$ & $(20)$ \\
\hline \multicolumn{6}{|l|}{ High-tech work } \\
\hline \multirow[t]{2}{*}{ Low Tech $\times$ Task Discretion } & $0.306 *$ & $0.226 *$ & 0.006 & $0.159 * * *$ & 0.069 \\
\hline & $(0.130)$ & $(0.100)$ & $(0.038)$ & $(0.035)$ & $(0.108)$ \\
\hline \multirow{3}{*}{$\begin{array}{l}\text { Low Tech } \times \text { Wider } \\
\text { Organizational Participation }\end{array}$} & 0.029 & $0.133^{*}$ & 0.028 & 0.018 & 0.029 \\
\hline & $(0.066)$ & $(0.055)$ & $(0.028)$ & $(0.018)$ & $(0.055)$ \\
\hline & $(2 I)$ & $(22)$ & $(23)$ & $(24)$ & $(25)$ \\
\hline \multicolumn{6}{|l|}{ High-skill work } \\
\hline \multirow[t]{2}{*}{ Low Skill $\times$ Task Discretion } & $0.553 * * *$ & $0.426 * * *$ & 0.065 & $0.211 * * *$ & $0.262^{*}$ \\
\hline & $(0.131)$ & $(0.101)$ & $(0.038)$ & $(0.037)$ & $(0.110)$ \\
\hline Low Skill $\times$ Wider & 0.079 & $0.158^{* *}$ & 0.014 & $0.055^{*}$ & 0.015 \\
\hline Organizational Participation & $(0.067)$ & $(0.056)$ & $(0.020)$ & $(0.020)$ & $(0.062)$ \\
\hline$N$ & 7,725 & 7,725 & 5,217 & 7,725 & 7,725 \\
\hline
\end{tabular}

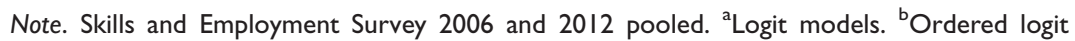
models. 'Ordinary least square models. Models include main effects of interaction terms, main and interaction terms for medium tech/medium skill, and all controls shown in Table I. Standard errors are given in parenthesis.

$* p<05 . * * p<0$ I. *** $p<00$ I.

and a measure of personality. The analyses were restricted to the much smaller sample for 2012, given that this was the only survey including the learning disposition and personality variables. The variables for preferences, learning disposition, and personality were added to models that included the controls presented in Table 1.

The first two rows of Table 4 show the base model effects of task discretion and organizational participation for learning for the 2012 survey taken on its own (taking the sample for which full information is available on all variables included). The second half of the table shows the coefficients for participation once the impact of preferences and personality have been taken into account. The effects of the individual-specific characteristics did indeed prove substantial, as reflected in the lower coefficients for the two forms of direct participation. However, it is also notable that the earlier impact of direct participation on the different aspects of both training and learning remained positive and (with the exception of the relation between task discretion and knowledge sharing) statistically significant even when such factors were taken into account. 
Table 4. Effects of Direct Participation on Learning With Controls for Training Preferences, Learning Disposition, and Personality.

\begin{tabular}{|c|c|c|c|c|c|}
\hline & $\begin{array}{c}\text { Training } \\
\text { incidence }^{\mathrm{a}}\end{array}$ & $\begin{array}{l}\text { Training } \\
\text { duration }^{\mathrm{b}}\end{array}$ & $\begin{array}{l}\text { Training } \\
\text { quality }^{c}\end{array}$ & $\begin{array}{l}\text { Learning } \\
\text { demands }{ }^{c}\end{array}$ & $\begin{array}{l}\text { Knowledge } \\
\text { sharing }\end{array}$ \\
\hline & $(26)$ & (27) & (28) & (29) & (30) \\
\hline \multicolumn{6}{|l|}{ Base } \\
\hline \multirow[t]{2}{*}{ Task discretion } & -0.126 & -0.124 & $0.09 \mid * *$ & $0.083^{* *}$ & $0.190^{*}$ \\
\hline & $(0.108)$ & $(0.085)$ & $(0.028)$ & $(0.028)$ & $(0.085)$ \\
\hline \multirow{3}{*}{$\begin{array}{l}\text { Wider organizational } \\
\text { participation }\end{array}$} & $0.173^{* *}$ & $0.134 * *$ & $0.060 * * *$ & 0.027 & $0.207^{* * *}$ \\
\hline & $(0.056)$ & $(0.044)$ & $(0.015)$ & $(0.014)$ & $(0.045)$ \\
\hline & $(3 \mathrm{I})$ & $(32)$ & (33) & (34) & $(35)$ \\
\hline \multicolumn{6}{|c|}{ With controls for preferences, learning disposition, and personality } \\
\hline \multirow[t]{2}{*}{ Task discretion } & -0.086 & -0.12 & $0.069 *$ & $0.057^{*}$ & 0.114 \\
\hline & $(0.108)$ & $(0.088)$ & $(0.028)$ & $(0.027)$ & $(0.087)$ \\
\hline \multirow{2}{*}{$\begin{array}{l}\text { Wider organizational } \\
\text { participation }\end{array}$} & $0.145^{*}$ & $0.103 *$ & $0.054 * * *$ & 0.022 & $0.192 * * *$ \\
\hline & $(0.055)$ & $(0.044)$ & $(0.015)$ & $(0.0 \mid 4)$ & $(0.047)$ \\
\hline$N$ & 2,175 & 2,175 & $\mathrm{I}, 532$ & 2,175 & 2,175 \\
\hline
\end{tabular}

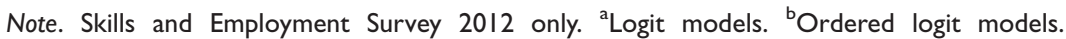
'Ordinary least square models. All models include main controls shown in Table I. Standard errors are given in parenthesis.

$* p<05$. $* * p<0$ I. $* * * p<00$ I.

Overall, it seems unlikely that the effects of direct participation can be accounted for in terms of either the earlier choices of the individuals affected or their general dispositional characteristics.

\section{Discussion}

This article has focused on the implications of direct participation for learning at work, examining in turn the opportunity to receive training, the quality of the training received, and the prevalence of informal learning. Our evidence confirms arguments that there is a significant association between direct participation and learning, but it also points to the need to distinguish between specific forms of participation as they have distinctive implications for particular types of learning. Moreover, it shows that the strength of the effects of direct participation for learning varies to some extent depending on technology level of the work setting and skill level of the employee. This relationship between participation and learning was substantially unaffected by various measures that were introduced to address direction of causality and person fixed-effects. 
It is organizational participation that had the strongest effects on the likelihood that employees will participate in training and the duration of training that they receive, while task discretion was not significantly related to training receipt. This confirms the view that, given that managerial decisions about training are likely to be taken at workplace level, it is influence over wider organizational decisions that is particularly crucial. In contrast, both task discretion and organizational participation were significantly related to better quality training, in the sense of training that leads to skill improvement. This suggests that the effectiveness of training schemes may depend on the ability of employees to be able to experiment in their jobs with what they have learned-a possibility that requires significant scope for individual discretion in the way the job task is carried out.

Both types of participation were also associated with greater opportunities for personal learning through the job and with a higher likelihood that people share knowledge with their colleagues, although in this case it is task discretion that emerged as the stronger factor. This is consistent with the qualitative literature on job design and informal learning. Employees learn on the job primarily through a process of trial and error and this requires a definition of work roles that allows them to exercise initiative over the order of tasks and the methods they use. Overall, then, the distinctiveness of the effects of particular forms of participation for particular types of learning provided some confirmation for the initial expectation that task discretion would have the greatest influence over informal learning and organizational participation over training provision, although training quality was a case where both types of participation are important.

Turning to potential moderator effect of advanced technologies and skill level, the qualitative literature indicated that the effects of direct participation for learning processes would be greater in jobs that involved advanced technology, but in practice, they were stronger in more routine work settings. Similarly, we expected direct participation to be more effective in facilitating learning outcomes for more highly skilled employees, but our evidence indicates that it benefited most those in lower skilled class positions. Interpretation of this must necessarily be rather speculative. But it seems possible that those in relatively advantaged positions whether with respect to the innovativeness of the technological setting or the complexity of their job tasks are recognized by employers as having high priority for training, while their jobs inherently pose the challenges that stimulate new learning. It is those in less advantageous positions whose learning needs can be easily overlooked 
and who are in jobs that risk being constructed as repetitive and routine who most need the specific leverage given by direct participation to enhance their learning opportunities at work.

These effects were robust with respect to a wide range of controls relating to the nature of work and organizational context. A test for prior change in task discretion was consistent with the view that participation has causal implications for learning. Moreover, all of the key effects persisted, albeit weakened, when we introduced variables to control for possible selection factors with respect to training preferences, learning disposition, and personality.

\section{Conclusion}

In focusing on the implications of direct participation for learning at work, this article contributes to the wider literature on the quality of work that has reemerged in the wake of the Great Recession. This has emphasized the need for responses both to the problems for motivation and well-being that derive from poor work design and to the expansion of low-skilled poor-quality jobs as a result of the polarized nature of occupational change (Kalleberg, 2011; Appelbaum, 2012; FernandezMacias, 2012; Correll, Kelly, O'connor, \& Williams, 2014). ${ }^{6}$

While there has been recognition in discussions of work redesign of the role of participation in reducing varied sources of stress in the work environment (inter alia: Chandola, 2010; Gallie \& Zhou, 2013b; Perlow \& Kelly, 2014; Glavin \& Schieman, 2012), there has been little research to date, based on representative samples of employees, of its implications for skill enhancement. Our results provide support for the view that direct participation significantly enhances learning at work in terms of both training and informal learning. At the same time, they indicate that there is a need for diverse forms of direct participation, as task discretion and organizational participation have distinctive effects for different forms of learning.

While confidence in these results is increased by the fact that they are derived from a representative cross-section of the workforce, rather than from selected and possibly atypical groups of employees, there is considerable scope for further research to test their robustness. The results are based on cross-sectional data, and although an effort has been made to take account of potentially prior influences, there is clearly a need for more rigorous testing of causal sequence through longitudinal research (although this would require new data sets). It must also be remembered that the information about employee work roles and consultative arrangements are derived from employees. While there are grounds 
for thinking that employees may be the best placed sources of information on practices that involve effective participation rather than merely formal procedure, it would be preferable to be able to test the robustness of the conclusions using data on organizational structure drawn both from employers and from employees. Finally, although the mechanisms we postulate could be expected to be relevant across very diverse types of capitalist society, their generalizability needs rigorous testing through comparative analyses.

If the pattern in our data is confirmed by subsequent research, it has substantial implications for policy. Given concerns about polarization, it is of special note that, while the benefits of direct participation are fairly general across the workforce, they are particularly strong for those in less favorable work contexts. It is those in jobs that have been traditionally disadvantaged with respect to learning at work who receive the greatest benefits from direct participation. Increasing the prevalence of direct participation among those in lower skilled jobs may then be a potentially important lever for upgrading the skills of those in poor-quality jobs, thereby helping to reduce inequalities in job quality.

Comparative research suggests that policy initiatives can be effective in raising levels of direct participation. There is now consistent evidence of substantial differences between European societies both in the typical levels of discretion that employees can exercise over their job tasks and in the extent to which they can influence wider organizational decisions (Gallie, 2007; Gallie \& Zhou 2013a, 2013b). It is particularly noteworthy that direct participation is more common in the Nordic countries where there have been sustained policy initiatives to redesign work in a way that increases employees' control over their job tasks and to encourage the active involvement of employees in decisions about organizational change. While it is unlikely that other societies can draw directly on the policy instruments that have been deployed in the Nordic countries, there may well be different types of policy lever that will be effective in enhancing participation in other institutional contexts. Even in liberal economies, such as the United States and the United Kingdom, for instance, a heightened transparency of job task quality and arrangements for organizational consultation might be achieved through company reporting requirements (possibly backed by independent audit), allowing potential employees greater scope to introduce considerations of the quality of the working environment into their choices of employer. A cultural emphasis on individual choice and market mechanisms could then be drawn upon to strengthen pressures for job redesign and workplace reform. ${ }^{7}$ 


\section{Appendix}

Table AI. Construction of Indices.

\begin{tabular}{|c|c|}
\hline Indicator & Items \\
\hline $\begin{array}{l}\text { Learning disposition } \\
\text { index }\end{array}$ & $\begin{array}{l}\text { To what extent do the following statements apply to } \\
\text { you? } \\
\text {-When I hear or read about new ideas, I try to relate } \\
\text { them to real-life situations to which they might apply } \\
\text {-I like learning new things } \\
\text {-When I come across something new, I try to relate it } \\
\text { to what I already know } \\
\text {-I like to get to the bottom of difficult things } \\
\text {-I like to figure out how different ideas fit together } \\
\text {-If I don't understand something, I look for additional } \\
\text { information to make it clearer }\end{array}$ \\
\hline $\begin{array}{l}\text { Work with advanced } \\
\text { technology }\end{array}$ & $\begin{array}{l}\text {-Does your own job involve use of computerized or } \\
\text { automated equipment? } \\
\text {-How important is using a computer, PC, or other types } \\
\text { of computerized equipment? } \\
\text {-Describe your use of computers or computerized } \\
\text { equipment in your job: straightforward, moderate, } \\
\text { complex, or advanced } \\
\text {-In your workplace, what proportion of employees } \\
\text { work with computerized or automated equipment? }\end{array}$ \\
\hline People work & $\begin{array}{l}\text { In your job, how important is . . } \\
\text {-Counseling, advising or caring for customers or clients? } \\
\text {-Managing your own feelings? } \\
\text {-Handling the feelings of other people? }\end{array}$ \\
\hline Personality & $\begin{array}{l}\text { Could you tell me how strongly you agree or disagree } \\
\text { that the following statements apply to you. I see } \\
\text { myself as . . } \\
\text {-Extroverted, enthusiastic } \\
\text {-Critical, quarrelsome } \\
\text {-Dependable, self-disciplined } \\
\text {-Anxious, easily upset } \\
\text {-Open to new experiences, complex } \\
\text {-Reserved, quiet } \\
\text {-Sympathetic, warm } \\
\text {-Disorganized, careless } \\
\text {-Calm, emotionally stable } \\
\text {-Conventional, uncreative }\end{array}$ \\
\hline
\end{tabular}


Table A2. Summary Statistics: Learning Outcomes and Direct Participation.

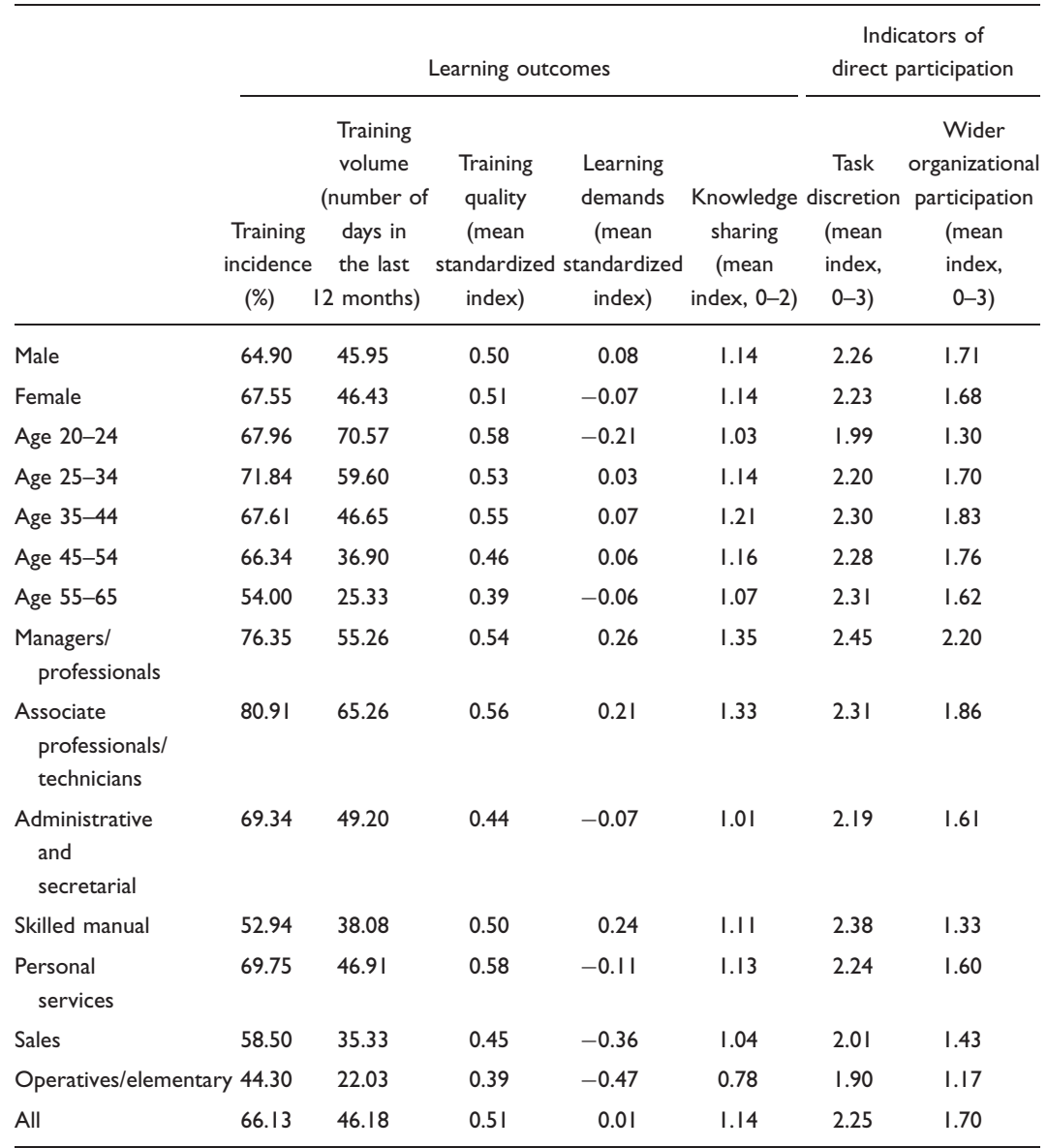

Note. Skills and Employment Survey 2006 and 2012 pooled data, weighted frequencies and means.

\section{Declaration of Conflicting Interests}

The authors declared no potential conflicts of interest with respect to the research, authorship, and/or publication of this article.

\section{Funding}

The authors disclosed receipt of the following financial support for the research, authorship, and/or publication of this article: The Skills and Employment Survey 
2012 used in this paper was funded by the Economic and Social Research Council (ESRC)/UK Commission for Employment and Skills (UKCES) Strategic Partnership (grant number RES-241-25-0001), with additional support from the Wales Institute of Social and Economic Research, Data and Methods.

\section{Notes}

1. The series includes six surveys in total collected in 1986, 1992, 1997, 2001, 2006, and 2012.

2. This compression particularly affects the personality measures in this study, although as we discuss later these have been validated by other research.

3. For further details, see Felstead, Gallie, Green, and Zhou (2007) and www.cardiff.ac.uk/socsi/ses2012.

4. The Brant test for ordered logistic models showed that the proportionality assumption was not met. However, we have checked that alternative models (i.e., heterogeneous choice models and generalized ordered logit models following Williams, 2010) that do not assume proportionality produce broadly the same estimates. This suggests that the practical implications of violation of proportionality assumption are not substantial in these particular cases. Given that the presentation of other models would be much more cumbersome, we have retained the estimates derived from the ordered logit regressions. However, results from these alternative models are available upon request from the first author.

5. Work groups that were able to exercise substantial influence over their immediate work activities were defined as semiautonomous teams and those which were not only able to influence the work process but also had substantial say in the selection of group members and leaders and setting targets were defined as self-managed teams.

6. An influential synthesis of much recent research is Kalleberg. Notably, there have been special issues of Work and Occupations both on "Precarious Work in Polarizing Times" (a symposium on Arne Kalleberg's Good Jobs, Bad Jobs), in 2012, and on "Redesigning, Redefining Work" in 2014.

7. For a more detailed discussion of potential policy levers, see Felstead, Gallie, and Green (2015).

\section{References}

Appelbaum, E. (2012). Reducing inequality and insecurity: Rethinking labor and employment policy for the 21st century. Work and Occupations, 39(4), 311-320. Appelbaum, E., Bailey, T., Berg, P., \& Kalleberg, A. L. (2000). Manufacturing advantage. Why high performance work systems pay off. Ithaca, NY: Cornell University.

Aoyama, Y., \& Castells, M. (2002). An empirical assessment of the informational society: Employment and occupational structures of G7 countries, 1920-2000. International Labour Review, 141(1-2), 123-159. 
Arulampalam, W., \& Booth, A. (1998). Training and labour market flexibility: Is there a trade-off? British Journal of Industrial Relations, 36, 521-536. doi:10.1111/1467-8543.00106

Bell, D. (1974). The coming of post-industrial society. London, England: Heinemann.

Blauner, R. (1964). Alienation and freedom. The factory worker and his industry. Chicago, IL: University of Chicago Press.

Blumberg, P. (1968). Industrial democracy: The sociology of participation. London, England: Constable.

Boreham, N., Fischer, M., \& Samurcay, R. (2004). Work process knowledge. London, England: Routledge.

Boxall, P., \& Purcell, J. (2010). An HRM perspective on employee participation. In A. Wilkinson, P. J. Gollan, M. Marchington, \& D. Lewin (Eds.), The Oxford handbook of participation in organizations (pp. 29-51). Oxford, England: Oxford University Press.

Böheim, R., \& Booth, A. (2004). Trade union presence and employer-provided training in Great Britain. Industrial Relations: A Journal of Economy and Society, 43(3), 520-545.

Braverman, H. (1974). Labor and monopoly capital. The degradation of work in the twentieth century. New York, NY: Monthly Review Press.

Canduela, J., Dutton, M., Johnson, S., Lindsay, C., McQuaid, R., \& Raeside, R. (2012). Ageing, skills and participation in work-related training in Britain: Assessing the position of older workers. Work, Employment \& Society, 26(1), 42-60.

Card, D., \& DiNardo, J. E. (2002). Skill-biased technological change and rising wage inequality. Journal of Labor Economics, 20(4), 733-783.

Castells, M., \& Aoyama, Y. (1994). Paths towards the informational society-Employment structure in G-7 countries, 1920-90. International Labour Review, 133(1), 5-33.

Chandola, T. (2010). Stress at work. London, England: The British Academy.

Conceição, P., Heitor, M. V., \& Lundvall, B.-A. (2003). Innovation, competence building and social cohesion in Europe. Towards a learning society. Cheltenham, England: Edward Elgar.

Correll, S. J., Kelly, E. L., O'connor, L. T., \& Williams, J. C. (2014). Redesigning, redefining work. Work and Occupations, 41(1), 3-17.

Darrah, C. N. (1996). Learning and work: An exploration in industrial ethnography. New York, NY: Garland Publishing.

European Council. (2000). Lisbon European Council 23 and 24 March 2000: Presidency Conclusions. Retrieved from http://www.europarl.europa.eu/ summits/lis__en.htm

Felstead, A. (2010). Closing the age gap? Age, skills and the experience of work in Great Britain. Ageing and Society, 30(8), 1293-1314.

Felstead, A., Fuller, A., Jewson, N., \& Unwin, L. (2009). Improving working as learning. London, England: Routledge. 
Felstead, A., Gallie, D., \& Green, F. (2015). Policies for intrinsic job quality. In A. Felstead, D. Gallie \& F. Green (Eds.), Unequal Britain at work (pp. 191-214). Oxford, England: Oxford University Press.

Felstead, A., Gallie, D., Green, F., \& Zhou, Y. (2007). Skills at work 1986-2006. Oxford, England: ESRC Centre on Skills, Knowledge and Organizational Performance (SKOPE).

Felstead, A., Gallie, D., Green, F., \& Zhou, Y. (2010). Employee involvement, the quality of training and the learning environment: An individual-level analysis. International Journal of Human Resource Management, 21(10), 1667-1688.

Fernandez-Macias, E. (2012). Job polarization in Europe? Changes in the employment structure and job quality, 1995-2007. Work and Occupations, 39(2), 157-182.

Gallie, D. (Ed.),. (2007). Employment regimes and the quality of work. Oxford, England: Oxford University Press.

Gallie, D., \& Zhou, Y. (2013a). Work organization and employee involvement in Europe. Luxembourg: Eurofound, Publications Office of the European Office.

Gallie, D., \& Zhou, Y. (2013b). Job control, work intensity and work stress. In D. Gallie (Ed.), Economic crisis, quality of work and social integration: The European experience (pp. 115-141). Oxford, England: Oxford University Press.

Glavin, P., \& Schieman, S. (2012). Work-family role blurring and work-family conflict: The moderating influence of job resources and job demands. Work and Occupations, 39(1), 71-98.

Gonzalez, M. C. (2009). The multidimensional impact of workplace direct participation in European jobs: An assessment of theory, debate and research. In A. M. Guillen \& S.-A. Dahl (Eds.), Quality of work in the European Union (pp. 189-215). Brussels, Belgium: Peter Lang.

Gosling, S. D., Rentfrow, P. J., \& Swann, W. B. Jr. (2003). A very brief measure of the Big-Five personality domains. Journal of Research in Personality, 37, 504-528.

Halldén, K. (2015). Taking training to task: Sex of the immediate supervisor and men's and women's time in initial on-the-job training. Work and Occupations, 42(1), 73-102.

Heller, F., Pusic, E., Strauss, G., \& Wilpert, B. (1998). Organizational participation: Myth and reality. Oxford, England: Oxford University Press.

Hirschhorn, L. (1984). Beyond mechanization. Cambridge, MA: The MIT Press.

Kalleberg, A. (2011). Good jobs, bad jobs: The rise of polarised and precarious employment systems in the United States, 1970s-2000s. New York, NY: Russell Sage Foundation.

Lawler, E. E. (1986). High involvement management. San Francisco, CA: Jossey-Bass.

Lawler, E., \& Ledford, E. Jr. (1992). A skill-based approach to human resource management. European Management Journal, 10(4), 383-391.

Legge, K. (1995). Human resource management: Rhetorics and realities. Basingstoke, England: Macmillan. 
Muck, P. M., Hell, B., \& Gosling, S. D. (2007). Construct validation of a short five-factor model instrument: A self-peer study on the German adaptation of the Ten-Item Personality Inventory (TIPI-G). European Journal of Psychological Assessment, 23(3), 166-175.

Oiry, E. (2003). De la qualification à la compétence, rupture ou continuité? Paris: L'Harmattan.

Perlow, L. A., \& Kelly, E. L. (2014). Toward a model of work redesign for better work and better life. Work and Occupations, 41(1), 111-134.

Purcell, J. (1993). The challenge of human resource management for industrial relations research and practice. International Journal of Human Resource Management, 4(3), 511-527.

Thompson, M. (2005). High-performance workplaces: Learning from aerospace. In J. Storey (Ed.), Adding value through information and consultation (pp. 69-88). Basingstoke, England: Palgrave Macmillan.

Walton, R. E. (1985). From control to commitment in the workplace. Harvard Business Review, 85(2), 77-84.

Wenger, E. (1998). Communities of practice: Learning, meaning and identity. Cambridge, England: Cambridge University Press.

Wilkinson, A., Gollan, P. J., Marchington, M., \& Lewin, D. (2010). Conceptualizing employee participation in organizations. In A. Wilkinson, P. J. Gollan, M. Marchington, \& D. Lewin (Eds.), Oxford handbook of organizations. Oxford, England: Oxford University Press.

Williams, R. (2010). Fitting heterogeneous choice models with OGLM. Stata Journal, 10(4), 540-567.

Willmott, H. (1993). Strength is ignorance; slavery is freedom: Managing culture in modern organizations. Journal of Management Studies, 30(4), 515-552.

Zhou, Y. (2009). British employees' organizational participation. Trends, determinants and impact. Berlin: VDM Verlag Dr. Muller.

\section{Author Biographies}

Hande Inanc is a policy analyst at the OECD Statistics Directorate. Her research focuses on quality of work, labor market insecurity and the life course, and subjective well-being. Before joining the OECD, she was a postdoctoral researcher at Nuffield College, University of Oxford, where she is currently an associate member.

Ying Zhou is a lecturer of human resource management at the University of Surrey. Her research focuses on employee skills, organizational involvement, nonstandard labor contracts, and quality of work life. Before joining the University of Surrey, she worked as a consultant at the Organizational Surveys and Insights unit of Towers Watson. She 
is currently an associate member of Nuffield College, Oxford University.

Duncan Gallie, CBE FBA, is an Emeritus Fellow of Nuffield College, Oxford and professor of sociology in the University of Oxford. His research has focused on comparative European studies of the quality of employment and of unemployment. He was foreign secretary and vice president of the British Academy (2006-2011).

Alan Felstead is a research professor at the Cardiff School of Social Sciences, Cardiff University. His research focuses on the quality of work; training, skills, and learning; nonstandard employment; and the spaces and places of work. He is currently editing Unequal Britain at Work with Duncan Gallie and Francis Green.

Francis Green is a professor of work and education economics at the LLAKES Centre, Institute of Education, London University. His research focuses on skills, training, work quality, and industrial relations issues. His most recent book (2013) is Skills and Skilled Work. An Economic and Social Analysis from Oxford University Press. 